\title{
A feasibility study on the association between residential greenness and neurocognitive function in middle-aged Bulgarians
}

\author{
Angel M. Dzhambov' ${ }^{1}$ Karamfil M. Bahchevanov², Kostadin A. Chompalov², and \\ Penka A. Atanassova ${ }^{2}$ \\ ${ }^{1}$ Department of Hygiene and Ecomedicine, Faculty of Public Health, Medical University of Plovdiv, Plovdiv, Bulgaria \\ ${ }^{2}$ Department of Neurology, Faculty of Medicine, Medical University of Plovdiv, Bulgaria
}

[Received in July 2019; Similarity Check in July 2019; Accepted in August 2019]

\begin{abstract}
Recent research has indicated that exposure to residential vegetation ("greenness") may be protective against cognitive decline and may support the integrity of the corresponding brain structures. However, not much is known about these effects, especially in less affluent countries and in middle-aged populations. In this study, we investigated the associations between greenness and neurocognitive function. We used a convenience sample of 112 middle-aged Bulgarians and two cognitive tests: the Consortium to Establish a Registry for Alzheimer's Disease Neuropsychological Battery (CERADNB) and the Montreal Cognitive Assessment (MoCA). In addition, structural brain imaging data were available for 25 participants. Participants' home address was used to link cognition scores to the normalised difference vegetation index (NDVI), a measure of overall neighbourhood vegetation level (radii from 100 to 1,000 m). Results indicated that higher NDVI was consistently associated with higher CERAD-NB and MoCA scores across radial buffers and adjustment scenarios. Lower waist circumference mediated the effect of NDVI on CERAD-NB. NDVI ${ }_{100-m}$ was positively associated with average cortical thickness across both hemispheres, but these correlations turned marginally significant $(\mathrm{P}<0.1)$ after correction for false discovery rate due to multiple comparisons. In conclusion, living in a greener neighbourhood might be associated with better cognitive function in middle-aged Bulgarians, with lower central adiposity partially accounting for this effect. Tentative evidence suggests that greenness might also contribute to structural integrity in the brain regions regulating cognitive functions. Future research should build upon our findings and investigate larger and more representative population groups.
\end{abstract}

KEY WORDS: cognitive function; green spaces; MRI; natural outdoor environments; neurodevelopment

Dementia is characterised by objective impairment in cognitive domains, such as deficits in memory and executive functions (1). The continuum of cognitive decline ranges from Alzheimer's disease, which accounts for 60 to $70 \%$ of cases (1), to prodromal forms like mild cognitive impairment, which affects 10-20\% of those aged 65 years and older (2). Dementia affects 47 million people worldwide and imposes a heavy burden on society $(\approx \$ 818$ billion in $2015)$, especially in low- and middle-income countries, where nearly $60 \%$ of people with dementia live (1). Less is known about the economics of mild cognitive impairment, but it is also associated with substantial costs (3).

Widely recommended interventions to prevent or delay cognitive decline include management of cerebrovascular risk factors (e.g. the metabolic syndrome constellation), promotion of physical and mental activity, and social interaction $(2,4,5)$. At the same time, various characteristics of the living environment have the potential to shape risk

\footnotetext{
Corresponding author: Asst. Professor Angel Dzhambov, MD, PhD Department of Hygiene and Ecomedicine, Faculty of Public Health, Medical University of Plovdiv, 15A Vassil Aprilov Blvd., 4002 Plovdiv, Bulgaria, E-mail: angelleloti@gmail.com
}

factors and health-enhancing behaviours. For instance, neighbourhood green vegetation (i.e., street trees, urban parks, and gardens - "greenness" in short) can mitigate air pollution and noise (6), two risk factors which can instigate neuroendocrine stress, inflammatory response, and alterations in neurotransmitter signalling in the brain regions (e.g. prefrontal cortex) responsible for regulation of cognitive functions $(7,8)$. Green environments require little top-down processing and provide opportunities for the restoration and recovery of the neurocognitive apparatus involved in sustaining directed attention (9-11). According to Browning and Alvarez's Scanning for Threats theory (12), green environments can dampen the brain's tendency to scan the surrounding environment for potential threats or dangers, which typically triggers sympathetic activation, and therefore protect the limbic system involved in danger signalling. Green spaces such as parks can engage local residents in outdoor physical activity and social interaction (6). From the clinical perspective, greenness appears protective against cardiovascular and cerebrovascular risk, as it can reduce high blood pressure $(13,14)$, cholesterol levels (15), and obesity (16), although the evidence remains 
inconclusive (17). In addition, emerging neuroscientific findings show that higher neighbourhood greenness might support structural integrity of those brain regions which are often associated with cognitive decline $(18,19)$. It is therefore conceivable that living in an environment with high amount of greenness may be conducive to healthenhancing experiences and behaviours and thus contribute to offsetting cognitive impairment.

Despite these encouraging findings, however, not much is known about the effects of greenness on neurocognitive function, especially in less affluent countries and in middleaged populations, in whom subtle precursors of cognitive impairment have been studied poorly $(1,6)$. The aim of this exploratory study was therefore to address these gaps in literature in a sample of middle-aged Bulgarians whose home address could be linked retrospectively to performance on several cognitive tests and in a subsample whose structural brain imaging data were available. The intent was to evaluate the feasibility of a future large-scale research in Bulgaria and other countries.

\section{PARTICIPANTS AND METHODS}

\section{Study design and sampling}

The present cross-sectional study takes advantage of data originally collected to investigate vascular risk factors for possible mild cognitive impairment in middle-aged individuals (20). The data were collected between 2014 and 2016 in the District of Plovdiv, Bulgaria. Participants were examined at the Departments of Neurology and Endocrinology at "St George" University Hospital, Plovdiv. We included literate volunteers aged between 45 and 55 years and excluded patients with decompensated chronic diseases (other than hypertension/diabetes), psychiatric disorders (e.g. depression), dementia, addiction to alcohol/ drugs, and those taking medication that could influence carbohydrate/lipid metabolism.

The participants were asked to complete a questionnaire asking about basic demographic, lifestyle, and healthrelated factors. They also underwent a clinical examination and neuropsychological evaluation. Residential addresses needed for assignment of geographic variables were obtained from participants' medical records. Participants had lived in their current home for at least five years.

From the database of 120 individuals we excluded those with missing outcome data and unsuccessfully geocoded residential address, which left us with a sample of 112 participants. Brain magnetic resonance imaging (MRI) was performed in a subsample of 25 participants, and these data were used for an exploratory analysis.

Informed consent was obtained from all participants prior to participation in the study. The study protocol adhered to the Declaration of Helsinki and was approved by the University Ethics Committee.

\section{Cognitive function assessment}

Participants were examined by a trained clinical neuropsychologist. Overall level of cognitive function was assessed with two validated neuropsychological tests. The main outcome was the Consortium to Establish a Registry for Alzheimer's Disease Neuropsychological Battery (CERAD-NB). CERAD-NB was developed to be a reliable and standardized tool for measuring primary cognitive manifestations of Alzheimer's disease (21) and has already been used to study environmental determinants of cognitive function (22). It consists of the following subtests: Verbal Fluency (VF), modified Boston Naming Test (BNT), Constructional Praxis (CP), Word List Memory (WLM), Word List Recall (WLR), and Word List Recognition (WLRc). They tap different aspects of memory deficits, such as verbal productivity, semantic memory, visual perception, immediate and delayed memory, learning ability of non-associated verbal material, and visual-constructive abilities (23). Each subtest was scored based on the sum of points from successfully completed answers. The total score (0 to 100) from these subtests was calculated according to the method proposed by Chandler et al. (23).

For comparison, we used another supplementary screening tool for mild cognitive impairment, the Montreal Cognitive Assessment (MoCA) (24). MoCA is often used to differentiate cognitive impairment from normal cognitive aging (25).

\section{Structural brain imaging}

High resolution anatomical images were acquired for 25 participants using the MAGNETOM Aera 1.5T magnetic resonance scanner (Siemens Healthcare, Erlangen, Germany) (26). Image outputs were visually inspected for any artefacts by an experienced neuroradiologist. A subsequent automated morphometric analysis of raw brain scans allowed investigation of the relationships between residential greenness and brain structure. Structural MRI T1 MPRAGE 3D images (acquisition matrix 232/256, slice thickness $0.9 \mathrm{~mm}, 192$ slices, voxel size T $0.9 \mathrm{~mm}$, TE 4,28 TR 1620, FoV 240*265, TI 918) were automatically processed using Freesurfer v. 5.3.0 (Laboratory for Computational Neuroimaging at Athinoula A. Martinos Center for Biomedical Imaging, Harvard University, Charlestown, MA, USA). Post-processing (surface-based methods) consisted of several steps to obtain cortical thickness values for brain regions of interest (27-29) based on the Desikan Atlas (30). Cortical thickness values were extracted and used for subsequent investigation of the relationships between residential greenness and brain structure. Our hypothesis was that higher residential greenness would be associated with greater cortical thickness in several brain regions. Informed by previously reported relations of brain structure with cognitive function $(31,32)$ and greenness exposure $(18,19)$, we narrowed the 
scope down to the following regions of interest in both hemispheres:

- Frontal lobe - superior frontal gyrus; rostral and caudal middle frontal gyrus; inferior frontal gyrus (pars opercularis, pars triangularis, and pars orbitalis); lateral and medial orbitofrontal gyrus; precentral gyrus; and paracentral gyrus;

- $\quad$ Parietal lobe - precuneus;

- Temporal lobe - fusiform gyrus, entorhinal cortex, parahippocampal gyrus;

- Occipital lobe - cuneus;

- Amygdala and hippocampus;

- Insular cortex.

\section{Residential greenness}

Residential greenness was operationalised as the normalised difference vegetation index (NDVI) (33), commonly employed as a proxy for overall vegetation level $(6,19,34,35)$. It ranges from -1 to +1 , where positive values closer to 1 indicate high greenness (36). NDVI was calculated based on the difference of Earth's surface reflectance in two vegetation-informative wavelengths, visible red (RED) and near infrared (NIR) light: $\mathrm{NDVI}=(\mathrm{NIR}-\mathrm{Red}) /(\mathrm{NIR}+\mathrm{RED})$. For these calculations, we used a single cloud-free Landsat 8 Operational Land Imager satellite image at a resolution of 30x30 m, obtained on 9 July 2015 to capture maximum summertime greenness within the timeframe of data collection (retrieved from: https://earthexplorer.usgs.gov/). Informed by expert recommendations, negative pixel values were removed from the raster before NDVI assignment to partial out the effect of water bodies in the residential area, which may also be beneficial for neurodevelopment (6). Mean NDVI was abstracted in the radii of $100 \mathrm{~m}, 300 \mathrm{~m}, 500 \mathrm{~m}$, and $1000 \mathrm{~m}$ around the residence (37). Geographic data were managed and calculated using QGIS 3.8.0 (OSGeo, Chicago, IL, USA) and ArcGIS 10.3 (ESRI, Redlands, CA, USA).

\section{Other covariates}

Relying on available literature, we determined additional covariates that could attenuate or otherwise modify the effect of NDVI on neurocognitive function, and used them in several alternative statistical models adjusting for their effect. We had self-reported data on participants' sex, age, education (secondary school or university), smoking (pack-years of smoking), and alcohol consumption (yes or no).

Waist circumference was measured according to the WHO protocol (38). Morning blood pressure was measured according to the American Heart Association guidelines using a calibrated aneroid sphygmomanometer with standard cuff-size (39).

Morning venous blood samples were drawn in a sitting position after an overnight fast and collected by nurses using standard serum-separating vacutainers. The samples were analysed for total cholesterol and blood glucose using enzymatic methods and automated biochemical analysers.

Nitrogen dioxide $\left(\mathrm{NO}_{2}\right)$ levels were taken from a map with a resolution of $100 \times 100 \mathrm{~m}$ generated from a global land use regression model using data from air quality monitoring stations, satellite readings, and other common geographic variables related to air pollution (40).

Road traffic day-evening-night noise $\left(\mathrm{L}_{\text {den }}\right)$ levels were available for participants residing in the city of Plovdiv $(n=83)$, which has a strategic noise map (41) in line with the EU Directive 2002/49/EC (42). $\mathrm{L}_{\text {den }}$ was modelled for the year 2016 using the CNOSSOS-EU noise model (43). Each address was inspected visually on a noise contour map, and building façades were assigned $\mathrm{L}_{\text {den }}$ in $5-\mathrm{dB}$ exposure bins (from 55 to $80 \mathrm{~dB}$ ). For the analyses, we considered $\mathrm{L}_{\text {den }}$ at the least exposed façade, because it provided greater exposure contrast between participants' addresses. Population in the 500-m radius around home and the city of residence (Plovdiv vs other) was taken as a proxy for urbanicity (44).

\section{Statistical analysis}

Inspection of the dataset indicated that no covariate had more than $10 \%$ of missing values. The values were missing at random and were imputed using the expectationmaximisation algorithm (45). The outcome variables had normal or close-to-normal distributions and were therefore analysed with parametric methods (46).

Descriptive statistics and correlations were used to identify general patterns of association between the data. We then employed multivariate linear regression models to investigate the relationships of NDVI with CERAD-NB and MoCA total scores. We also looked at specific CERAD subtests. The main model (Model 1) was adjusted for sex, age, education, city, and population in the $500 \mathrm{~m}$ radius. We also designed alternative models to test whether additional covariates or putative mediators would attenuate the effect of NDVI. They were all based on Model 1 but also included the following covariates: smoking and alcohol consumption (Model 2); waist circumference, systolic blood pressure, total cholesterol, and blood glucose (Model 3); $\mathrm{NO}_{2}$ (Model 4); and $\mathrm{L}_{\text {den }}$ (Model 5). To control for coexposure to $\mathrm{NO}_{2}$ as a confounding variable that highly correlated with NDVI (tolerance $<0.2$ and Variance Inflation Factor $>5$ ), we first regressed $\mathrm{NO}_{2}$ against NDVI in the respective radius and then used model residuals as a covariate in Model 4 (47).

Next we tested single mediation models linking NDVI $_{100-\mathrm{m}}$ to CERAD-NB total score via the following putative mediators: waist circumference, systolic blood pressure, total cholesterol, glucose, and $\mathrm{NO}_{2} . \mathrm{L}_{\text {den }}$ was not measured on a truly continuous scale and was not suitable for mediation modelling. We used the PROCESS 2.16 macro (48). $95 \%$ CIs of indirect effects were estimated with bias-corrected bootstrapping (5000 samples). 
NDVI $_{100-m}$, which was found to be the best statistical predictor of cognitive function in the main analysis, was used for the analysis of cortical thickness in a subsample of 25 participants. We computed Pearson correlations with cortical thickness in the a priori selected brain regions of interest. To control for false discovery rate due to multiple comparisons (proportion of type I errors), we applied the Benjamini-Hochberg correction method (49).

Data were processed with SPSS Statistics for Windows v. 17 (SPSS Inc., Chicago, MI, USA), and associations were considered statistically significant at the $\mathrm{P}<0.05$ level (2-tailed).

\section{RESULTS}

\section{Sample characteristics and bivariate associations}

Characteristics of the study sample are presented in Table 1. Mean age was 50 years and the majority of

Table 1 Characteristics of the study sample

\begin{tabular}{|c|c|}
\hline Characteristics & $\mathrm{N}=112$ \\
\hline \multicolumn{2}{|l|}{ Sociodemographic factors } \\
\hline Age, years (mean, SD) & $49.99(3.34)$ \\
\hline $\operatorname{Men}(n, \%)$ & $41(36.6)$ \\
\hline Higher education $(\mathrm{n}, \%)$ & $82(73.2)$ \\
\hline \multicolumn{2}{|l|}{ Greenness } \\
\hline $\mathrm{NDVI}_{100-\mathrm{m}}$ (median, IQR) & $0.39(0.10)$ \\
\hline $\mathrm{NDVI}_{300-\mathrm{m}}($ median, IQR) & $0.40(0.07)$ \\
\hline $\mathrm{NDVI}_{500-\mathrm{m}}($ median, IQR) & $0.40(0.08)$ \\
\hline $\mathrm{NDVI}_{1000-\mathrm{m}}($ median, IQR) & $0.41(0.09)$ \\
\hline \multicolumn{2}{|l|}{ Cognitive function } \\
\hline CERAD-NB (mean, SD) & $82.45(7.77)$ \\
\hline MoCA (mean, SD) & $26.01(2.69)$ \\
\hline \multicolumn{2}{|l|}{ Other covariates } \\
\hline $\begin{array}{l}\text { Pack-years of smoking (median, } \\
\text { IQR) }\end{array}$ & $7.00(18.00)$ \\
\hline Alcohol consumption (n, \%) & $76(67.9)$ \\
\hline $\begin{array}{l}\text { Waist circumference, } \mathrm{cm} \\
(\text { mean, SD) }\end{array}$ & $94.22(15.03)$ \\
\hline $\begin{array}{l}\text { Systolic blood pressure, } \mathrm{mmHg} \\
\text { (mean, SD) }\end{array}$ & $119.86(12.51)$ \\
\hline $\begin{array}{l}\text { Total cholesterol, } \mathrm{mmol} / \mathrm{L} \\
\text { (mean, SD) }\end{array}$ & $5.87(1.14)$ \\
\hline Glucose, mmol/L (mean, IQR) & $5.47(1.15)$ \\
\hline $\mathrm{NO}_{2}, \mu \mathrm{g} / \mathrm{m}^{3}$ (mean, SD) & $18.66(4.03)$ \\
\hline $\mathrm{L}_{\mathrm{den}}>65 \mathrm{~dB}(\mathrm{~A})(\mathrm{n}, \%)^{\mathrm{a}}$ & $46(41.1)$ \\
\hline Residence in Plovdiv city (n, \%) & $83(74.1)$ \\
\hline Population $_{500-\mathrm{m}}$ (median, IQR) & $8381.17(7108.51)$ \\
\hline $\begin{array}{l}\text { CERAD-NB - Consortium to Establis } \\
\text { Disease Neuropsychological Battery } \\
\mathrm{L}_{\text {den }} \text { - day-evening-nigh noise level; } \mathrm{N} \\
\text { vegetation index; MoCA - Montreal } \\
\text { - nitrogen dioxide; SD - standard } \\
\text { available for participants residing in }\end{array}$ & $\begin{array}{l}\text { egistry for Alzheimer's } \\
\text { - interquartile range; } \\
\text { - normalised difference } \\
\text { itive Assessment; } \mathrm{NO}_{2} \\
\text { lation; }{ }^{a} \mathrm{~L}_{\text {den }} \text { was only } \\
\text { ity of Plovdiv }(\mathrm{n}=83)\end{array}$ \\
\hline
\end{tabular}

participants had higher education and were women. Bivariate Spearman correlations (Table 2) show that better cognitive function (i.e., higher CERAD score) was associated with higher greenness in the $100-\mathrm{m}$ radius. NDVI within other radii did not seem to contribute to cognitive function or other biomedical variables. CERAD-NB was also associated with higher educational level, female sex, lower waist circumference, lower systolic blood pressure, and, surprisingly, higher $\mathrm{NO}_{2}$ and $\mathrm{L}_{\text {den }}$. Correlations between the geographic variables were in line with literature - higher greenness was inversely related to population density, $\mathrm{NO}_{2}$, and $\mathrm{L}_{\mathrm{den}}$.

\section{Associations between greenness and cognitive function}

Table 3 shows multivariate correlations between NDVI and cognitive function. Higher NDVI was consistently associated with higher CERAD-NB and MoCA scores across the radii and adjustment models. This effect was most pronounced for NDVI ${ }_{100-m}$. However, when we re-run the main model for each CERAD subtest individually, $\mathrm{NDVI}_{100-\mathrm{m}}$ significantly correlated only with verbal fluency $(\beta=1.47 ; 95 \%$ CI: $0.60,2.34)$.

Single mediation models showed that higher NDVI was associated with higher CERAD-NB score through lower waist circumference across all radii (Table 4). None of the other factors acted as a mediator.

\section{Greenness and cortical thickness}

First we compared the participants with MRI data to the rest to check whether any selection bias was at play. Table 5 clearly shows that there were no materially important differences between the two groups, except for the significantly higher pack-years of smoking in the subsample of 25 participants with MRI.

The analysis of the brain regions of interest showed that $\mathrm{NDVI}_{100-\mathrm{m}}$ positively correlated with average cortical thickness across both hemispheres, more specifically in several gyri across the prefrontal cortex, bilateral fusiform gyrus, left precuneus and insula, and right cuneus (Table 6). These correlations largely survived adjustment for sex, age, education, city, and population in the 500-m radius (data not shown). However, none of them remained significant $(\mathrm{P}<0.1)$ after correction for false discovery rate (Table 6).

\section{DISCUSSION}

\section{Overall findings}

We found evidence that higher greenness was consistently associated with better performance on two distinct cognitive tests. This association was partly mediated by lower waist circumference. Our sub-analysis also suggested that higher greenness might support structural integrity in relevant brain regions. 


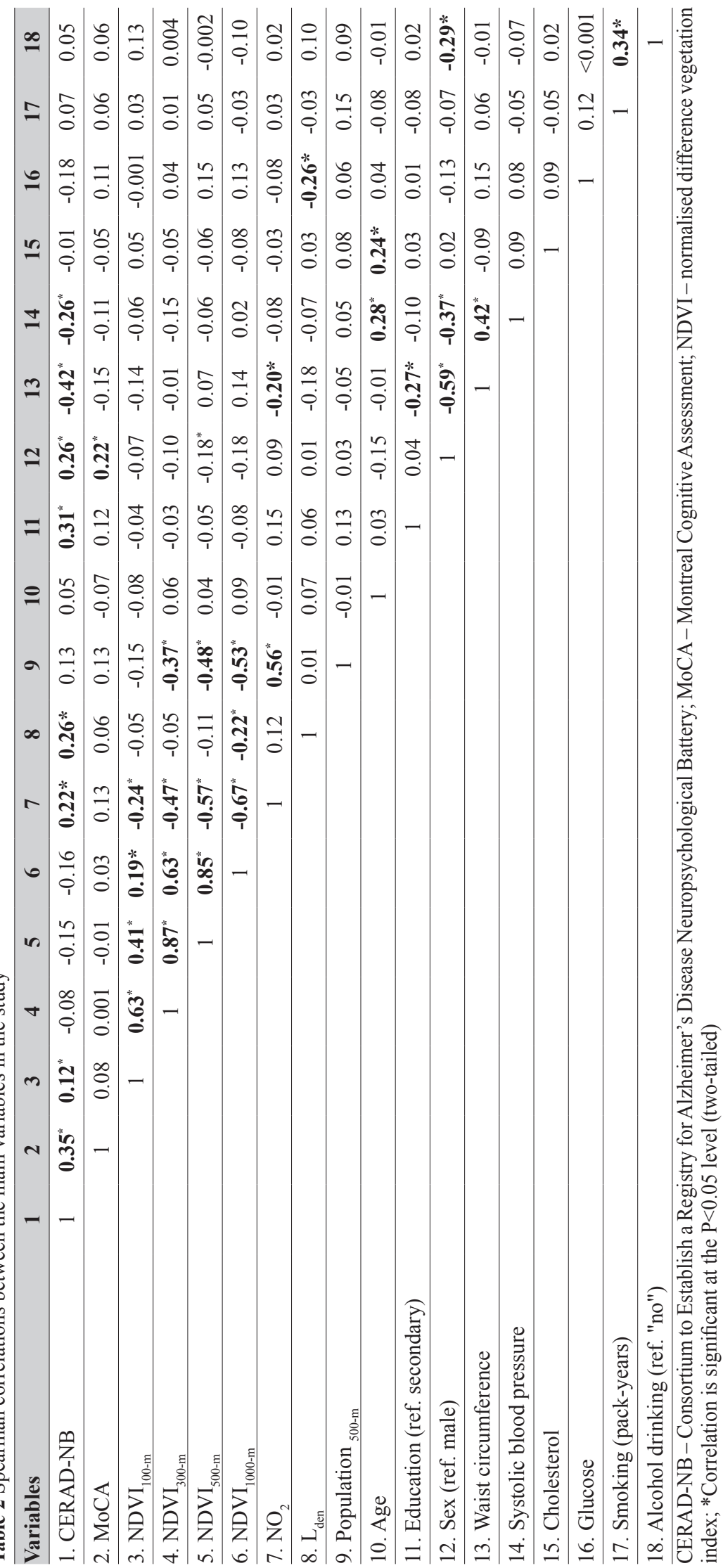



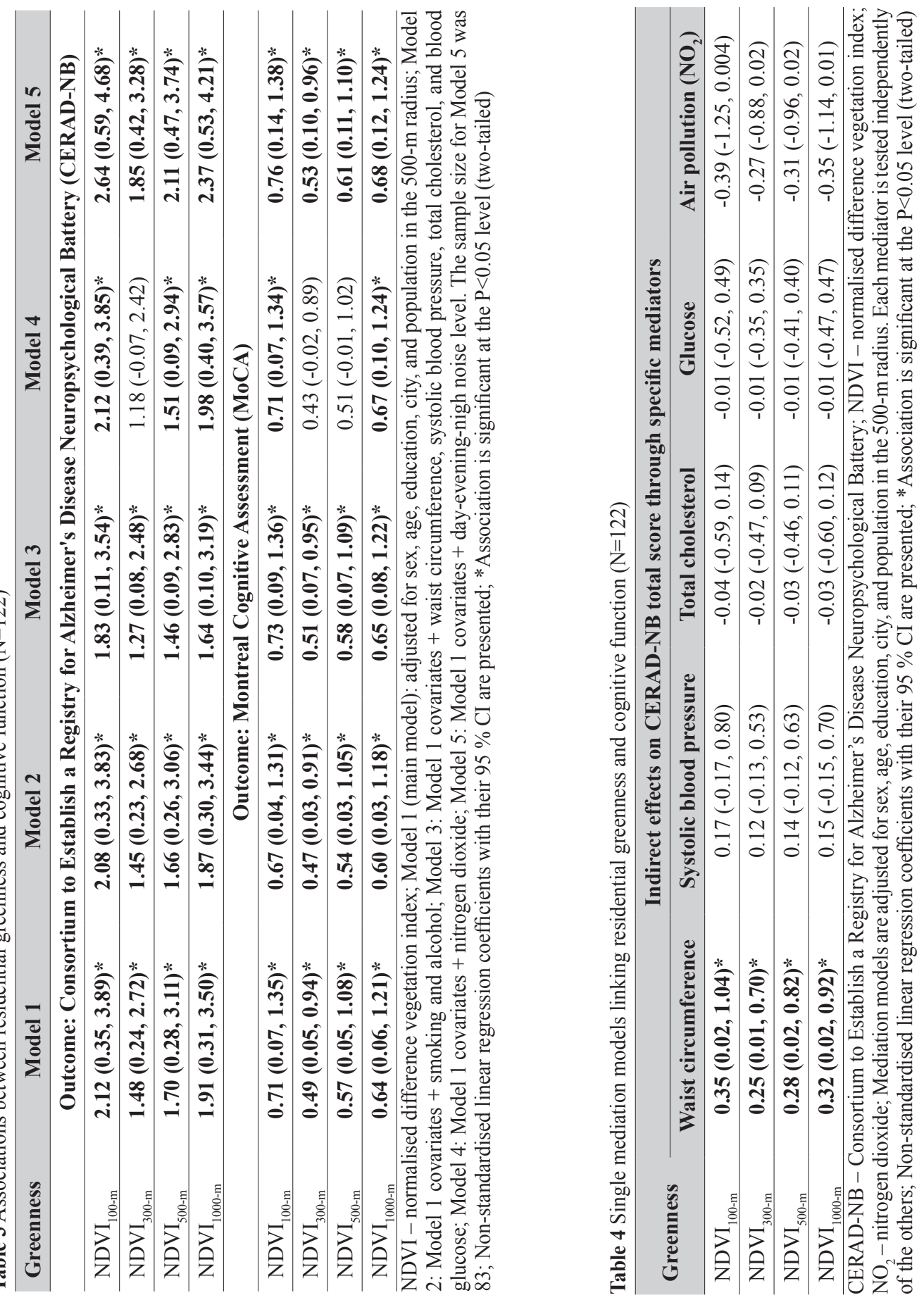
Greenness is a feature of the living environment that has been receiving growing attention as potentially beneficial influence on cognitive function in children and adults. Our findings support earlier epidemiological research showing protective effect on several cognitive domains $(19,34,35,50,51)$. For example, Dadvand et al. (50) observed enhanced working memory and lower inattentiveness in children exposed to greenness, both at school and neighbourhood. This beneficial effect on attention was corroborated by another study that looked at lifelong exposure to residential greenness during preschool and early primary school years (34). Cognitive decline over a 10-year follow-up was slower in middle-aged British civil servants living in greener neighbourhoods (35), and another study showed that proximity to nature benefited cognitive function (51). Interestingly, when we looked into specific subtests, greenness was positively associated only with verbal fluency, which measures semantic memory and executive functions (cognitive flexibility) (23). However, at this point, we can offer no clear explanation of these findings. Other authors (22) have also reported significant association between exposure to traffic noise and some CERAD subtests.

Mechanisms believed to mediate these benefits are complex and manifold (6). For example, vegetation biomass can mitigate concentrations of some air pollutants and disrupt propagation of sound waves, which, in turn, have been linked to impaired neurocognitive function (7). We observed counterintuitive bivariate associations between $\mathrm{NO}_{2}$ and $\mathrm{L}_{\text {den }}$ with CERAD-NB, even though literature reports detrimental effects on neurodevelopment. For instance, Tzivian et al. (52) reported positive associations between long-term air pollution and traffic noise exposures and mild cognitive impairment, with some evidence of synergistic effects (53). Another recent study (22) observed inverse relationships between noise levels and total cognition as well as constructional praxis in elderly women tested with CERAD. To our knowledge, only two studies have tested mediation by air pollution/noise; one (51) did not find any such evidence in adults, but the other (34) showed partial mediation by traffic-related air pollution in children. Clearly, further research on these potential mediators is needed.

Table 5 Comparison of characteristics between participants with MRI (brain region of interest data) and those without MRI

\begin{tabular}{|c|c|c|c|}
\hline Characteristics & $\begin{array}{c}\text { No MRI data } \\
(n=87)\end{array}$ & $\begin{array}{l}\text { With MRI data } \\
\quad(n=25)\end{array}$ & P-value \\
\hline \multicolumn{4}{|l|}{ Sociodemographic factors } \\
\hline Age, years (mean, SD) & $50.06(3.39)$ & $49.73(3.20)$ & 0.682 \\
\hline $\operatorname{Men}(\mathrm{n}, \%)$ & $35(38.9)$ & $6(27.3)$ & 0.459 \\
\hline Higher education (n, \%) & $66(73.3)$ & $16(72.7)$ & 1.000 \\
\hline \multicolumn{4}{|l|}{ Greenness } \\
\hline $\mathrm{NDVI}_{100-\mathrm{m}}($ mean, SD) & $0.39(0.08)$ & $0.40(0.09)$ & 0.684 \\
\hline $\mathrm{NDVI}_{300-\mathrm{m}}($ mean, $\mathrm{SD})$ & $0.40(0.06)$ & $0.41(0.06)$ & 0.263 \\
\hline $\mathrm{NDVI}_{500-\mathrm{m}}$ (mean, SD) & $0.41(0.06)$ & $0.43(0.07)$ & 0.111 \\
\hline $\mathrm{NDVI}_{1000-\mathrm{m}}($ mean, SD) & $0.42(0.07)$ & $0.44(0.08)$ & 0.361 \\
\hline \multicolumn{4}{|l|}{ Cognitive function } \\
\hline CERAD-NB (mean, SD) & $82.44(7.99)$ & $82.77(3.90)$ & 0.858 \\
\hline MoCA (mean, SD) & $26.08(2.84)$ & $25.73(1.98)$ & 0.585 \\
\hline \multicolumn{4}{|l|}{ Other covariates } \\
\hline Pack-years of smoking (median, IQR) & $2.25(15.00)$ & $13.75(23.50)$ & 0.001 \\
\hline Alcohol consumption (n, \%) & $62(68.9)$ & $14(63.6)$ & 0.621 \\
\hline Waist circumference, $\mathrm{cm}$ (mean, SD) & $93.31(14.69)$ & $97.14(16.45)$ & 0.287 \\
\hline Systolic blood pressure, mmHg (mean, SD) & $119.11(12.47)$ & $122.05(13.15)$ & 0.330 \\
\hline Total cholesterol, mmol/L (mean, SD) & $5.96(1.17)$ & $5.50(0.91)$ & 0.087 \\
\hline Glucose, mmol/L (mean, IQR) & $5.36(0.99)$ & $5.92(1.60)$ & 0.040 \\
\hline $\mathrm{NO}_{2}, \mu \mathrm{g} / \mathrm{m}^{3}$ (mean, SD) & $19.01(4.00)$ & $17.52(4.12)$ & 0.122 \\
\hline $\mathrm{L}_{\mathrm{den}}>65 \mathrm{~dB}(\mathrm{~A})(\mathrm{n}, \%)^{\mathrm{a}}$ & $37(56.1)$ & $9(52.9)$ & 1.000 \\
\hline Residence in Plovdiv city (n, \%) & $66(73.3)$ & $17(77.3)$ & 0.792 \\
\hline Population $_{500-\mathrm{m}}($ median, IQR) & $8930.64(6334.30)$ & $6587.49(7331.20)$ & 0.433 \\
\hline
\end{tabular}

CERAD-NB - Consortium to Establish a Registry for Alzheimer's Disease Neuropsychological Battery; IQR - interquartile range; $\mathrm{L}_{\text {den }}$ - day-evening-nigh noise level; NDVI - normalised difference vegetation index; MoCA - Montreal Cognitive Assessment; MRI - magnetic resonance imaging; $\mathrm{NO}_{2}$ - nitrogen dioxide; $\mathrm{SD}$ - standard deviation; ${ }^{\mathrm{a}} \mathrm{L}_{\mathrm{den}}$ was only available for participants residing in the city of Plovdiv $(\mathrm{n}=83)$ 
We also tested several cardiovascular risk factors (abdominal adiposity, high blood pressure, high cholesterol, and glucose) as potential mediators and found that only waist circumference mediated the effect of greenness. This is in line with findings that proximity to green spaces and overall residential greenness may be conducive to physical health (54) and protect against obesity (16), and that, in turn, abdominal obesity is predictive of cognitive impairment (55). We speculate that it would take a long-term prospective study (as opposed to our cross-sectional one) to establish the real effect of the other potential mediators analysed in our study.

Only a handful of studies have looked into the associations between residential greenness and brain structure. Our exploratory MRI of 25 participants suggests that greenness within the 100-m radius of the residence may preserve the average cortical thickness across brain regions whose thinning is otherwise associated with cognitive impairment and Alzheimer's disease $(31,32)$. Despite the low statistical power of our analysis, the direction of associations was consistent with previous neuroimaging findings of positive association between lifelong exposure to greenness and grey matter volume in the prefrontal and premotor cortex of children (19). Kühn et al. (18) reported forest within $1 \mathrm{~km}$ radius of home benefits amygdalar integrity. One possible explanation is that neighbourhood features like parks and street vegetation along commuting lines provide diverse sensory experience and thus elicit processes behind brain plasticity $(18,56,57)$.

Contact with natural landscapes may promote perceived restorative quality and reduce exposure to traffic noise and air pollution, thus stimulating outdoor social interaction and physical activity $(6,44)$. In turn, these processes have been related to positive alterations in brain structures implicated in mental well-being and cognition. For example, perceived restorative quality has been linked to lower activation of the bilateral cuneus, precuneus, and the right cingulate gyrus (58); the amygdala has been implicated in modulating neural networks involved in social cognition (59); and physical activity has been reported to positively correlate with brain matter volume in hippocampal gyrus and white matter volume in precuneus and posterior cingulate gyrus (60). Collectively, these findings encourage further investigation of the effects of neighbourhood greenness on the brain and the underlying mechanisms of these effects. It is important to understand to what extent psycho-social and ecological mediators that mediate the effects of greenness (6) contribute to changes in the brain structures that shape neurocognitive functions.

\section{Strengths and limitations}

Our exploratory study has several limitations. First, its cross-sectional design precludes establishing causality. Although the participants resided in their current home for the last five years, we had no information on their residential history, which would be needed to estimate lifelong exposure to greenness (cf. 19). However, we consider it unlikely that changes in the brain structure or cognitive function would influence participants' choice of residence. Despite this conservative scenario, the surprisingly consistent protective associations of greenness with CERAD-NB and MoCA support our working hypothesis. However, all significant correlations with cortical thickness disappeared after false discovery rate correction. Furthermore, we had a modest convenience sample that precludes any generalisation.

Informed by earlier literature $(34,35)$, we used summertime satellite images to calculate NDVI as a proxy for surrounding greenness (cf. 35). Although satellite imagebased measures capture overall amount of green vegetation, they do not account for actual interaction with it, such as visual exposure and spending time in green spaces (61). Current recommendations in the filed advocate considering daily mobility patterns (62), greenness visible from the eye-level (61), and operationalising interaction with greenness in a life-course perspective $(63,64)$. However, because this was a secondary analysis of an already existing clinical dataset, we did not have access to information that would allow for moving beyond static environmental exposure assessment. Even so, seasonal changes in vegetation cover were previously found to have little impact on the association between NDVI and mental health in Plovdiv (44).

Our analyses focused on greenness because highresolution data were not available for air pollution and noise. The $\mathrm{NO}_{2}$ map had a resolution of $100 \times 100 \mathrm{~m}$ and was generated using a global land use regression model that may not be optimal for capturing exposure contrasts at a fine spatial scale over a small territory such as the city of Plovdiv (40). $\mathrm{L}_{\text {den }}$ was taken from an EU noise map, but exposure data were only available in 5-dB isophones, limiting the number of distinct values in this variable and the power to detect small effects. Furthermore, we observed positive bivariate associations between these air/noise pollution and cognition. These counterintuitive findings may be due to the fact that $\mathrm{NO}_{2}$ and $\mathrm{L}_{\text {den }}$ are higher in downtown Plovdiv, where the socioeconomic standard is also higher and residents have better access to healthcare. However, this explanation is speculative, as we did not have neighbourhood-level data of either. Finally, blue spaces, which may also be beneficial for cognitive function, were not considered in this study, because they highly coincided with traffic sources in the study area (cf. 44).

Notwithstanding these limitations, this study has a number of strengths. To our knowledge, it is one of the few studies on residential greenness and cognitive function and the third one to attempt linking residential greenness to structural brain imaging data. We employed two clinically validated measures of cognitive function (CERAD and MoCA), as opposed to some larger epidemiological studies that used more crude tools (51). We also had information 
Table 6 Associations between residential greenness and cortical thickness $(\mathrm{N}=25)$

\begin{tabular}{|c|c|c|c|}
\hline Region of interest & $\begin{array}{l}\text { Pearson correlation } \\
\text { with } \text { NDVI }_{100-\mathrm{m}}\end{array}$ & $\begin{array}{l}\text { Uncorrected } \\
\text { P-value }\end{array}$ & $\begin{array}{c}\text { Benjamini-Hochberg } \\
\text { P-value }\end{array}$ \\
\hline Left paracentral gyrus & +0.558 & 0.007 & 0.089 \\
\hline Left lateral orbitofrontal gyrus & +0.529 & 0.011 & 0.089 \\
\hline Right fusiform gyrus & +0.526 & 0.012 & 0.089 \\
\hline Left precuneus & +0.514 & 0.014 & 0.089 \\
\hline Right cortical thickness & +0.503 & 0.017 & 0.089 \\
\hline Right cuneus & +0.500 & 0.018 & 0.089 \\
\hline Left cortical thickness & +0.494 & 0.019 & 0.089 \\
\hline Right lateral orbitofrontal gyrus & +0.491 & 0.020 & 0.089 \\
\hline Left fusiform gyrus & +0.480 & 0.024 & 0.089 \\
\hline Left caudal middle frontal gyrus & +0.474 & 0.026 & 0.089 \\
\hline Right medial orbitofrontal gyrus & +0.474 & 0.026 & 0.089 \\
\hline Right caudal middle frontal gyrus & +0.463 & 0.030 & 0.090 \\
\hline Left insula & +0.461 & 0.031 & 0.090 \\
\hline Left medial orbitofrontal gyrus & +0.446 & $\mathbf{0 . 0 3 7}$ & 0.101 \\
\hline Left pars triangularis & +0.440 & 0.040 & 0.102 \\
\hline Left superior frontal gyrus & +0.420 & 0.051 & 0.122 \\
\hline Right rostral middle frontal gyrus & +0.415 & 0.055 & 0.122 \\
\hline Left pars orbitalis & +0.404 & 0.062 & 0.132 \\
\hline Right precuneus & +0.389 & 0.074 & 0.148 \\
\hline Left rostral middle frontal gyrus & +0.358 & 0.102 & 0.186 \\
\hline Right superior frontal gyrus & +0.355 & 0.105 & 0.186 \\
\hline Right pars orbitalis & +0.352 & 0.108 & 0.186 \\
\hline Right pars triangularis & +0.330 & 0.133 & 0.211 \\
\hline Left pars opercularis & +0.328 & 0.137 & 0.211 \\
\hline Left entorhinal area & +0.326 & 0.139 & 0.211 \\
\hline Left cuneus & +0.299 & 0.176 & 0.254 \\
\hline Right entorhinal area & +0.296 & 0.181 & 0.254 \\
\hline Right parahippocampal gyrus & +0.288 & 0.194 & 0.263 \\
\hline Left hippocampus & -0.278 & 0.211 & 0.276 \\
\hline Right paracentral gyrus & +0.240 & 0.282 & 0.357 \\
\hline Right amygdala & +0.232 & 0.300 & 0.367 \\
\hline Right pars opercularis & +0.182 & 0.418 & 0.497 \\
\hline Left precentral gyrus & +0.152 & 0.501 & 0.577 \\
\hline Right hippocampus & -0.134 & 0.551 & 0.616 \\
\hline Right insula & +0.129 & 0.568 & 0.617 \\
\hline Right precentral gyrus & +0.079 & 0.726 & 0.766 \\
\hline Left amygdala & +0.056 & 0.806 & 0.827 \\
\hline Left parahippocampal gyrus & +0.022 & 0.921 & 0.921 \\
\hline
\end{tabular}

$\mathrm{NDVI}$ - normalised difference vegetation index; ${ }^{\mathrm{a}}$ Correction for false discovery rate 
on potential confounding/mediating lifestyle, biomedical, and environmental factors, which have not been considered as a set elsewhere. Another strength is that we sampled middle-aged individuals, who are an understudied group in the field, as opposed to other studies, which focused on either children $(19,34,50)$ or elderly populations $(35,52)$. Overall, we believe that these novel features justify the present feasibility work.

\section{CONCLUSIONS}

Living in a greener neighbourhood might be associated with better cognitive function in middle-aged Bulgarians. This effect is partly mediated by lower central adiposity. Tentative evidence suggests that greenness might also contribute to the structural integrity of the brain regions responsible for cognitive functions. Future research should build upon our findings and investigate larger, more representative population groups.

\section{Acknowledgments}

Research leading to these results received funding from the project "Clinical and Neuropsychological Target Screening for Early Diagnosis of Asymptomatic Cerebrovascular Disease in Clinically Healthy Persons in Adulthood” (№ 13/2014) and doctoral programme project "Magnetic Resonance Tomography and Cortisol Levels in Early Cognitive Disorders Association in Patients with Metabolic Syndrome” (№ SDP-12/2015). Angel Dzhambov's work on this paper was also partly supported by the National Programme "Young Scientists and Postdoctoral Candidates" of the Ministry of Education and Science of Bulgaria. The funding organisations had no role in the design or conduct of this research.

\section{Conflict of interest}

None to declare.

\section{REFERENCES}

1. World Health Organization (WHO). Global Action Plan on the Public Health Response to Dementia 2017 - 2025. Geneva: WHO; 2017.

2. Langa KM, Levine DA. The diagnosis and management of mild cognitive impairment: a clinical review. JAMA 2014;312:2551-61. doi: 10.1001/jama.2014.13806

3. Lin PJ, Neumann PJ. The economics of mild cognitive impairment. Alzheimers Dement 2013;9:58-62. doi: 10.1016/j.jalz.2012.05.2117

4. Jongsiriyanyong S, Limpawattana P. Mild cognitive impairment in clinical practice: a review article. Am J Alzheimers Dis Other Demen 2018;33:500-7. doi: $10.1177 / 1533317518791401$

5. World Health Organization (WHO). Risk Reduction of Cognitive Decline and Dementia: WHO Guidelines. Geneva: WHO; 2019
6. Markevych I, Schoierer J, Hartig T, Chudnovsky A, Hystad P, Dzhambov AM, de Vries S, Triguero-Mas M, Brauer M, Nieuwenhuijsen MJ, Lupp G, Richardson EA, Astell-Burt T, Dimitrova D, Feng X, Sadeh M, Standl M, Heinrich J, Fuertes E. Exploring pathways linking greenspace to health: Theoretical and methodological guidance. Environ Res 2017;158:301-17. doi: 10.1016/j.envres.2017.06.028

7. Tzivian L, Winkler A, Dlugaj M, Schikowski T, Vossoughi M, Fuks K, Weinmayr G, Hoffmann B. Effect of long-term outdoor air pollution and noise on cognitive and psychological functions in adults. Int J Hyg Environ Health 2015;218:1-11. doi: 10.1016/j.ijheh.2014.08.002

8. Clark C, Paunovic K. WHO Environmental Noise Guidelines for the European Region: A systematic review on environmental noise and cognition. Int J Environ Res Public Health 2018;15(2). pii: E285. doi: 10.3390/ijerph15020285

9. Kaplan S. The restorative benefits of nature: Towards an integrative framework. J Environ Psychol 1995;15:169-82. doi: 10.1016/0272-4944(95)90001-2

10. Kaplan R, Kaplan S. The Experience of Nature: Y Psychological Perspective. New York: Cambridge University Press; 1989.

11. Norwood MF, Lakhani A, Maujean A, Zeeman H, Creux O, Kendall E. Brain activity, underlying mood and the environment: A systematic review. J Environ Psychol 2019;65:101321. doi: 10.1016/j.jenvp.2019.101321

12. Browning MHEM, Olvera Alvarez HA. Editorial commentary: Scanning for threats and natural environments giving our reptilian brains a break. Trends Cardiovasc Med 2019;pii:S1050-1738(19)30097-0. doi: 10.1016/j. tcm.2019.07.006

13. Markevych I, Thiering E, Fuertes E, Sugiri D, Berdel D, Koletzko S, von Berg A, Bauer CP, Heinrich J. A crosssectional analysis of the effects of residential greenness on blood pressure in 10-year old children: results from the GINIplus and LISAplus studies. BMC Public Health 2014;14:477. doi: 10.1186/1471-2458-14-477

14. Dzhambov AM, Markevych I, Lercher P. Greenspace seems protective of both high and low blood pressure among residents of an Alpine valley. Environ Int 2018;121:443-52. doi: 10.1016/j.envint.2018.09.044

15. Yang BY, Markevych I, Heinrich J, Bloom MS, Qian Z, Geiger SD, Vaughn M, Liu S, Guo Y, Dharmage SC, Jalaludin B, Knibbs LD, Chen D, Jalava P, Lin S, Hung-Lam Yim S, Liu KK, Zeng XW, Hu LW, Dong GH. Residential greenness and blood lipids in urban-dwelling adults: The 33 Communities Chinese Health Study. Environ Pollut 2019;250:14-22. doi: 10.1016/j.envpol.2019.03.128

16. Persson $\AA$, Pyko A, Lind T, Bellander T, Östenson CG, Pershagen G, Eriksson C, Lõhmus M. Urban residential greenness and adiposity: A cohort study in Stockholm County. Environ Int 2018;121:832-41. doi: 10.1016/j. envint.2018.10.009

17. Twohig-Bennett C, Jones A. The health benefits of the great outdoors: a systematic review and meta-analysis of greenspace exposure and health outcomes. Environ Res 2018;166:628-37. doi: 10.1016/j.envres.2018.06.030

18. Kühn S, Düzel S, Eibich P, Krekel C, Wüstemann H, Kolbe J, Martensson J, Goebel J, Gallinat J, Wagner GG, Lindenberger $U$. In search of features that constitute an "enriched environment" in humans: Associations between 
geographical properties and brain structure. Sci Rep 2017;7:11920. doi: 10.1038/s41598-017-12046-7

19. Dadvand $\mathrm{P}$, Pujol J, Macià $\mathrm{D}$, Martínez-Vilavella $\mathrm{G}$, BlancoHinojo L, Mortamais M, Alvarez-Pedrerol M, Fenoll R, Esnaola M, Dalmau-Bueno A, López-Vicente M, Basagaña X, Jerrett M, Nieuwenhuijsen MJ, Sunyer J. The association between lifelong greenspace exposure and 3-dimensional brain magnetic resonance imaging in Barcelona schoolchildren. Environ Health Perspect 2018;126:027012. doi: 10.1289/EHP1876

20. Bahchevanov K. [Early neurological and cognitive impairment in metabolic syndrome, in Bulgarian]. [PhD thesis]. Plovdiv: Medical University of Plovdiv; 2017.

21. Morris JC, Heyman A, Mohs RC, Hughes JP, van Belle G, Fillenbaum G, Mellits ED, Clark C. The Consortium to Establish a Registry for Alzheimer's Disease (CERAD). Part I. Clinical and neuropsychological assessment of Alzheimer's disease. Neurology 1989;39:1159-65. doi: 10.1212/ wnl.39.9.1159

22. Fuks KB, Wigmann C, Altug H, Schikowski T. Road traffic noise at the residence, annoyance, and cognitive function in elderly women. Int J Environ Res Public Health 2019;16(10):pii: E1790. doi: 10.3390/ijerph16101790

23. Chandler MJ, Lacritz LH, Hynan LS, Barnard HD, Allen G, Deschner M, Weiner MF, Cullum CM. A total score for the CERAD neuropsychological battery. Neurology 2005;65:102-6. doi: 10.1212/01.wnl.0000167607.63000.38

24. Nasreddine ZS, Phillips NA, Bédirian V, Charbonneau S, Whitehead V, Collin I, Cummings JL, Chertkow H. The Montreal Cognitive Assessment, MoCA: a brief screening tool for mild cognitive impairment. J Am Geriatr Soc 2005;53:695-9. doi: 10.1111/j.1532-5415.2005.53221.x

25. Larner AJ. Screening utility of the Montreal Cognitive Assessment (MoCA): in place of - or as well as - the MMSE? Int Psychogeriatr 2012;24:391-6. doi: 10.1017/ S1041610211001839

26. Bahchevanov KM, Atanassova PA, Chompalov KA, Mitkov MD, Milev BI, Terzieva DD, Naydenov VI, Dosheva VS, Masaldjieva RI, Velkova KG, Sirakov NV, Kilova KP. Cortisol correlates with structural magnetic resonance imaging parameters in middle aged Bulgarian patients with metabolic syndrome: a pilot study. Folia Med (Plovdiv) 2018;60:546-52. doi: 10.2478/folmed-2018-0029

27. Fischl B, Dale AM. Measuring the thickness of the human cerebral cortex from magnetic resonance images. Proc Natl Acad Sci U S A 2000;97:11050-5. doi: 10.1073/ pnas. 200033797

28. Ségonne F, Dale AM, Busa E, Glessner M, Salat D, Hahn HK, Fischl B. A hybrid approach to the skull stripping problem in MRI. Neuroimage 2004;22:1060-75. doi: 10.1016/j.neuroimage.2004.03.032

29. Fischl B, Salat DH, Busa E, Albert M, Dieterich M, Haselgrove C, van der Kouwe A, Killiany R, Kennedy D, Klaveness S, Montillo A, Makris N, Rosen B, Dale AM. Whole brain segmentation: automated labeling of neuroanatomical structures in the human brain. Neuron 2002;33:341-55. doi: 10.1016/s0896-6273(02)00569-x

30. Desikan RS, Ségonne F, Fischl B, Quinn BT, Dickerson BC, Blacker D, Buckner RL, Dale AM, Maguire RP, Hyman BT, Albert MS, Killiany RJ. An automated labeling system for subdividing the human cerebral cortex on MRI scans into gyral based regions of interest. Neuroimage 2006;31:968-80. doi: 10.1016/j.neuroimage.2006.01.021

31. Ries ML, Carlsson CM, Rowley HA, Sager MA, Gleason CE, Asthana S, Johnson SC. Magnetic resonance imaging characterization of brain structure and function in mild cognitive impairment: a review. J Am Geriatr Soc 2008;56:920-34. doi: 10.1111/j.1532-5415.2008.01684.x

32. Yang H, Xu H, Li Q, Jin Y, Jiang W, Wang J, Wu Y, Li W, Yang C, Li X, Xiao S, Shi F, Wang T. Study of brain morphology change in Alzheimer's disease and amnestic mild cognitive impairment compared with normal controls. Gen Psychiatr 2019;32:e100005. doi: 10.1136/ gpsych-2018-100005

33. Tucker CJ. Red and photographic infrared linear combinations for monitoring vegetation. Remote Sens Environ 1979;8:12750. doi: 10.1016/0034-4257(79)90013-0

34. Dadvand P, Tischer C, Estarlich M, Llop S, Dalmau-Bueno A, López-Vicente M, Valentín A, de Keijzer C, FernándezSomoano A, Lertxundi N, Rodriguez-Dehli C, Gascon M, Guxens M, Zugna D, Basagaña X, Nieuwenhuijsen MJ, Ibarluzea J, Ballester F, Sunyer J. Lifelong residential exposure to green space and attention: A population-based prospective study. Environ Health Perspect 2017;125:097016. doi: 10.1289/EHP694

35. de Keijzer C, Tonne C, Basagaña X, Valentín A, SinghManoux A, Alonso J, Antó JM, Nieuwenhuijsen MJ, Sunyer J, Dadvand P. Residential surrounding greenness and cognitive decline: a 10-year follow-up of the Whitehall II cohort. Environ Health Perspect 2018;126:077003. doi: 10.1289/EHP2875

36. Gascon M, Cirach M, Martínez D, Dadvand P, Valentín A, Plasència A, Nieuwenhuijsen MJ. Normalized difference vegetation index (NDVI) as a marker of surrounding greenness in epidemiological studies: The case of Barcelona city. Urban For Urban Green 2016;19:88-94. doi: 10.1016/j. ufug.2016.07.001

37. Gascon M, Sánchez-Benavides G, Dadvand P, Martínez D, Gramunt N, Gotsens X, Cirach M, Vert C, Molinuevo JL, Crous-Bou M, Nieuwenhuijsen M. Long-term exposure to residential green and blue spaces and anxiety and depression in adults: A cross-sectional study. Environ Res 2018;162:2319. doi: 10.1016/j.envres.2018.01.012

38. World Health Organization (WHO). Waist Circumference and Waist-Hip Ratio: Report of a WHO Expert Consultation, Geneva, 8-11 December 2008. Geneva: WHO; 2011.

39. Muntner P, Shimbo D, Carey RM, Charleston JB, Gaillard T, Misra S, Myers MG, Ogedegbe G, Schwartz JE, Townsend RR, Urbina EM, Viera AJ, White WB, Wright JT Jr. Measurement of blood pressure in humans: a scientific statement from the American Heart Association. Hypertension 2019;73:e35-e66. doi: 10.1161/HYP.0000000000000087

40. Larkin A, Geddes JA, Martin RV, Xiao Q, Liu Y, Marshall JD, Brauer M, Hystad P. Global land use regression model for nitrogen dioxide air pollution. Environ Sci Technol 2017;51:6957-64. doi: 10.1021/acs.est.7b01148

41. Spectri. Разработване на актуализирани стратегически карти за шум на агломерация Пловдив [Development of Updated Strategic Noise Maps of Plovdiv Agglomeration, in Bulgarian] Sofia, 2016 [displayed 28 August 2019]. Available on http://www.plovdiv.webnoise.eu/PD16_NM_PRB1.pdf

42. Directive 2002/49/EC of the European Parliament and of the Council of 25 June 2002 relating to the assessment and 
management of environmental noise. Off J Eur Commun 2002;L189:12-25

43. Kephalopoulos S, Paviotti M, Anfosso-Lédée F. Common Noise Assessment Methods in Europe (CNOSSOS-EU). Luxembourg: Publications Office of the European Union; 2012.

44. Dzhambov A, Hartig T, Markevych I, Tilov B, Dimitrova D. Urban residential greenspace and mental health in youth: Different approaches to testing multiple pathways yield different conclusions. Environ Res 2018;160:47-59. doi: 10.1016/j.envres.2017.09.015

45. Dempster AP, Laird NM, Rubin DB. Maximum likelihood estimation from incomplete data via the EM algorithm. J Royal Stat Soc B 1977;39:1-38.

46. Blanca MJ, Alarcón R, Arnau J, Bono R, Bendayan R. Nonnormal data: Is ANOVA still a valid option? Psicothema 2017;29:552-7. doi: 10.7334/psicothema2016.383

47. Yang BY, Guo Y, Markevych I, Qian ZM, Bloom MS, Heinrich J, Dharmage SC, Rolling CA, Jordan SS, Komppula M, Leskinen A, Bowatte G, Li S, Chen G, Liu KK, Zeng XW, Hu LW, Dong GH. Association of long-term exposure to ambient air pollutants with risk factors for cardiovascular disease in China. JAMANetw Open 2019;2(3):e190318. doi: 10.1001/jamanetworkopen.2019.0318

48. Hayes AF. Introduction to Mediation, Moderation, and Conditional Process Analysis: A Regression-Based Approach. New York: Guilford Press; 2013.

49. Benjamini Y, Hochberg Y. Controlling the false discovery rate: a practical and powerful approach to multiple testing. J Royal Stat Soc B 1995;57:289-300. doi: 10.2307/2346101

50. Dadvand P, Nieuwenhuijsen MJ, Esnaola M, Forns J, Basagaña X, Alvarez-Pedrerol M, Rivas I, López-Vicente M, De Castro Pascual M, Su J, Jerrett M, Querol X, Sunyer J. Green spaces and cognitive development in primary schoolchildren. Proc Natl Acad Sci U S A 2015;112:7937-42. doi: 10.1073/pnas. 1503402112

51. Zijlema WL, Triguero-Mas M, Smith G, Cirach M, Martinez D, Dadvand P, Gascon M, Jones M, Gidlow C, Hurst G, Masterson D, Ellis N, van den Berg M, Maas J, van Kamp I, van den Hazel P, Kruize H, Nieuwenhuijsen MJ, Julvez J. The relationship between natural outdoor environments and cognitive functioning and its mediators. Environ Res 2017;155:268-75. doi: 10.1016/j.envres.2017.02.017

52. Tzivian L, Dlugaj M, Winkler A, Weinmayr G, Hennig F, Fuks KB, Vossoughi M, Schikowski T, Weimar C, Erbel R, Jöckel KH, Moebus S, Hoffmann B; Heinz Nixdorf Recall study Investigative Group. Long-term air pollution and traffic noise exposures and mild cognitive impairment in older adults: a cross-sectional analysis of the Heinz Nixdorf Recall Study. Environ Health Perspect 2016;124:1361-8. doi: 10.1289/ehp. 1509824

53. Tzivian L, Jokisch M, Winkler A, Weimar C, Hennig F, Sugiri D, Soppa VJ, Dragano N, Erbel R, Jöckel KH, Moebus S, Hoffmann B; Heinz Nixdorf Recall Study Group. Associations of long-term exposure to air pollution and road traffic noise with cognitive function-An analysis of effect measure modification. Environ Int 2017;103:30-8. doi: 10.1016/j. envint.2017.03.018

54. Browning M, Lee K. Within what distance does "greenness" best predict physical health? A systematic review of articles with GIS buffer analyses across the lifespan. Int J Environ Res Public Health 2017;14(7):pii: E675. doi: 10.3390/ ijerph14070675

55. Jagust W, Harvey D, Mungas D, Haan M. Central obesity and the aging brain. Arch Neurol 2005;62:1545-8. doi: 10.1001/archneur.62.10.1545

56. Baroncelli L, Braschi C, Spolidoro M, Begenisic T, Sale A, Maffei L. Nurturing brain plasticity: impact of environmental enrichment. Cell Death Differ 2010;17:1092-103. doi: 10.1038/cdd.2009.193

57. Tost H, Reichert M, Braun U, Reinhard I, Peters R, Lautenbach S, Hoell A, Schwarz E, Ebner-Priemer U, Zipf A, Meyer-Lindenberg A. Neural correlates of individual differences in affective benefit of real-life urban green space exposure. Nat Neurosci 2019;22:1389-93. doi: 10.1038/ s41593-019-0451-y

58. Tang C, Tsai Y-P, Lin Y-J, Chen J-H, Hsieh C-H, Hung S-H, Sullivan WC, Tang H-F, Chang C-Y. Using functional Magnetic Resonance Imaging (fMRI) to analyze brain region activity when viewing landscapes. Landscape Urban Plan 2017;162:137-44. doi: 10.1016/j.landurbplan.2017.02.007

59. Bickart KC, Dickerson BC, Barrett LF. The amygdala as a hub in brain networks that support social life. Neuropsychologia 2014;63:235-48. doi: 10.1016/j. neuropsychologia.2014.08.013

60. Demirakca T, Brusniak W, Tunc-Skarka N, Wolf I, Meier S, Matthäus F, Ende G, Schulze TG, Diener C. Does body shaping influence brain shape? Habitual physical activity is linked to brain morphology independent of age. World J Biol Psychiatry $2014 ; 15: 387-96$. doi : 10.3109/15622975.2013.803600

61. Helbich M, Yao Y, Liu Y, Zhang J, Liu P, Wang R. Using deep learning to examine street view green and blue spaces and their associations with geriatric depression in Beijing, China. Environ Int 2019;126:107-17. doi: 10.1016/j. envint.2019.02.013

62. Helbich M. Toward dynamic urban environmental exposure assessments in mental health research. Environ Res 2018;161:129-35. doi: 10.1016/j.envres.2017.11.006

63. Helbich M. Spatiotemporal contextual uncertainties in green space exposure measures: exploring a time series of the normalized difference vegetation indices. Int J Environ Res Public Health 2019;16(5):pii: E852. doi: 10.3390/ ijerph16050852

64. Helbich M. Dynamic Urban Environmental Exposures on Depression and Suicide (NEEDS) in the Netherlands: a protocol for a cross-sectional smartphone tracking study and a longitudinal population register study. BMJ Open 2019;9(8):e030075. doi: 10.1136/bmjopen-2019-030075 


\section{Istraživanje povezanosti stambenog zelenila s neurokognitivnom funkcijom u sredovječnih Bugara}

Najnovija istraživanja upućuju na to da izloženost vegetaciji u mjestu stanovanja ("zelenilu”) može usporiti pad kognitivne funkcije te očuvati cjelovitost s njom povezanih moždanih struktura. Međutim, malo se zna o takvom djelovanju zelenila, osobito u siromašnijim zemljama i populacijama srednje životne dobi. Stoga je u ovom istraživanju analizirana povezanost između zelenila i neurokognitivne funkcije na prigodnom uzorku od 122 sredovječna bugarska stanovnika koji su bili podvrgnuti dvama kognitivnim testovima: jednom za utvrđivanje znakova Alzheimerove bolesti (Consortium to Establish a Registry for Alzheimer's Disease Neuropsychological Battery, krat. CERAD-NB) te drugom za ocjenu kognitivne funkcije (Montreal Cognitive Assessment, krat. MoCA). Osim toga, dostupni su nam bili podaci dobiveni magnetnom rezonancijom moždanih struktura 25 sudionika. Njihove kućne adrese povezane su normaliziranim indeksom razlike $u$ vegetaciji (engl. Normalised Difference Vegetation Index, krat. NDVI) kojim se mjeri razina zelenila u četvrti (u polumjeru od 100 do $1000 \mathrm{~m}$ ). Rezultati pokazuju da je viši NDVI bez iznimke povezan s višim ocjenama testova CERAD-NB i MoCA kroz sve polumjere i statističke modele prilagođene po različitim kovarijatima. Na tu povezanost zelenila i testova posredno je utjecao opseg struka. NDVI u polumjeru od 100 metara od adrese stanovanja bio je povezan sa srednjom debljinom korteksa u objema moždanim polutkama, ali se ta povezanost pokazala marginalno značajnom $(\mathrm{P}<0,1)$ nakon korekcije zbog ocjene lažnoga otkrivanja uslijed višestrukih statističkih usporedbi. Zaključak je da život u zelenijoj četvrti može biti povezan s boljom kognitivnom funkcijom u sredovječnih Bugara te da na nju utječe i manji opseg struka. Naši rezultati također donekle upućuju na to da zelenilo pridonosi strukturnoj cjelovitosti moždanih područja koja upravljaju kognitivnim funkcijama. Buduća bi istraživanja trebala proširiti te rezultate obuhvativši veće i reprezentativnije populacijske skupine.

KLJUČNE RIJEČI: kognitivna funkcija; neurološki razvoj; NMR; prirodni okoliš; zelene površine 